International Journal of English Literature and Social Sciences
Vol-7, Issue-1; Jan-Feb, 2022
Journal Home Page Available: https://ijels.com/
Journal DOI: $10.22161 /$ ijels

Peer-Reviewed Journal

\title{
Analysis of the Novel Si Anak Pelangi by Tere Liye in the Study of Social Conflict
}

\author{
Riris Valentina Sihombing, Sarwiji Suwandi, Suyitno
}

Indonesian Language Education Postgraduate Program, Universitas Sebelas Maret, Surakarta, Indonesia

Received: 15 Dec 2021; Received in revised form: 29 Jan 2022; Accepted: 07 Feb 2022; Available online: 14 Feb 2022

(C)2022 The Author(s). Published by Infogain Publication. This is an open access article under the CC BY license

(https://creativecommons.org/licenses/by/4.0/).

\begin{abstract}
This study discusses the study of social conflict in the novel entitled Si Anak Pelangi by Tere Liye. In this study that each study of social conflict consists of social classes conflict, intergroup conflict, interpersonal conflict intergenerational conflict, social status and roles conflict. The purpose of this study was to determine the social conflict contained in the novel Si Anak Pelangi by Tere Liye. The research method used is a qualitative descriptive method. This research uses a sociology of literature approach. Data were collected by reading, recording, and analyzing the documents contained in the novel Si Anak Pelangi by Tere Liye. The results of this study indicate that in the study of social conflict there are social conflict consisting of social classes conflict, intergroup conflict, interpersonal conflict intergenerational conflict, social status and roles conflict
\end{abstract}

Keywords - Social Conflicts, Literature, Novel, Si Anak Pelangi.

\section{INTRODUCTION}

In social conflict, human beings often interact interactions carried out by people or someone with other people and society. Conflict that can change and develop human life for the better or worse. Social conflict does not just happen, because there are complex factors ranging from ethnic strength, social classes, and inequality. (Soekanto, 2015 , p. 91) states that the causes of social conflict in society include individual differences, interests, social and culture.

The existence of conflict in society by the authors used as an idea in making interesting literary works for readers. The combination of the author's imagination with close conflict in society will create literary works that are easily understood by literary connoisseurs. Literature is a work in the form of a written or spoken that expresses the thoughts or life of the author.

(Minnery, 1985, p. 35) states conflict as an interaction between two or more parties who are mutually dependent but separated by different goals where at least one of the parties is aware of these differences and acts against each other. According to (Soekanto, 2015, p. 99), social conflict is a phase in the social process that makes individuals/groups try to achieve their respective goals by opposing the opposing party accompanied by violence or threats. From the opinion above, it can be synthesized that social conflict is a dispute, difference of opinion, conflict that occurs between one or more individuals in society due to the influence of certain differences that cause reactions in the form of different actions from each individual or group.

(Abidin, 2014, p. 279) state that there are five types of social conflict, namely (a) social classes conflict; (b) intergroup conflict; (c) interpersonal conflict; (d) intergenerational conflict; (e) social status and roles conflict. The following is an explanation of the forms of social conflict as follows:

\section{a) Social Classes Conflict}

According to Mark in (Abidin, 2014, pp. 386-387) social class consists of free people and slaves, aristocrats and commoners, masters and servants, oppressors and the oppressed are always in conflict with each other which goes on and on in one fight, which is sometimes hidden, and exposed. This conflict occurs because of the differences in each level of social classes. This conflict usually occurs 
between two different social classes, such as between the rich class and the poor class, between the government (ruler) and the citizen (Ahmadi, 2009, p. 295).

\section{b) Intergroups Conflict}

Intergroup conflict is a conflict that occurs between two social groups caused by different interests or because of the same conflict of interest, competition arises. This intergroup conflict can involve race, ethnicity, religion, or certain sects or groups. This type of conflict can occur due to the struggle for opportunities for social mobility, for example the opportunity to obtain economic resources (land disputes between entrepreneurs and local residents), the opportunity to gain political power, or community recognition (Abidin, 2014, p. 279).

\section{c) Interpersonal Conflict}

Interpersonal conflict is a conflict that occurs between two individuals because of differences in interests or it could be due to the entry of individuals into groups that are not accepted by other group members. Interpersonal conflict can also occur between a person and one or more other people, the nature of that is sometimes the substance involves differences in ideas, opinions, interests, or is emotional in nature regarding differences in tastes, feelings of likes, dislikes.

\section{d) Intergenerational Conflict}

Intergenerational conflict is a conflict that occurs between two generations, namely the younger generation and the older generation due to differences in value orientations in society. This conflict can occur because on the one hand, the older generation still adheres to the old values so that they view what the younger generation is doing as a deviation of values. The younger generation as the other party uses a new value orientation, they look at the older generation as old-fashioned (Soetomo, 2013, p. 107).

\section{e) Social Status and Role Conflict}

Paul B. Horton in (Dhohiri, 2007, p. 16), defines status or position as a person's position in a social group. Every individual who occupies a certain status or position in society and carries out a role, is sometimes faced with conflict related to his status and role.

(Nurgiyantoro, 2013, p. 12) novel is a work of prose fiction that has sufficient length, not too long, but also not too short. Novel is part of a literary work. (Altenbernd, 1996, p. 14) define the novel as a narrative prose that is imaginative, but makes sense and contains the truth. In line with the above opinion in the journal (Angi Saputri, 2016) a novel is defined as a long prose essay, containing a series of stories from a person's life with the people around her by highlighting the character and actors. The novel also depicts some of the main characters' lives which are important, interesting, and contain conflict. Based on the description above, it can be concluded that the novel is a literary work which is often also referred to as fiction which describes a reality of life and behavior, which contains values written in good and imaginative language.

\section{METHOD}

This research method uses descriptive qualitative research. According to (Sugiyono., 2013, p. 1) states that qualitative research is research that is used to examine objects naturally. This research uses a sociology of literature approach. (Moleong, 2014, p. 6) states qualitative research as research that aims to understand what events/phenomenons are faced by research subjects such as behavior, motivation and so on which holistically uses a special natural context and utilizes natural methods. This research uses a sociology of literature approach. (Ratna, 2013 , p. 1) states that the sociology of literature is a science that studies human relations in society, which are general, rational, and empirical. Therefore, through the sociology of literature approach, it is used to explain/describe the forms of social conflict in the novel Si Anak Pelangi. The data collection technique applied in this research is document review (content analysis). (Sukmadinata, 2012, p. 220) document review is a technique by collecting and analysing important documents to support research.

In this study, the validity of the data was tested using triangulation techniques. (Moleong, 2014, p. 330) states that the most widely used triangulation technique is examination through other sources. In this study, the researchers used data source triangulation techniques and theoretical triangulation. Different data collection methods, namely the reading, recording and analysis of documents.

\section{RESULT AND DISCUSSION}

Social conflict is one of the causes of community disputes and opposing each other in opinion or behavior. Humans or society will not be able to live alone and even have to ask for help from others but must interact with fellow humans in order to fulfill their needs. In social conflict, human beings often interact - interactions carried out by people or someone with other people and society. Conflict that can change and develop human life for the better or worse. Social conflict do not just happen, because there are complex factors ranging from ethnic strength, social class, and inequality. (Soekanto, 2015, p. 91) causes social conflict in society, among others, are individual differences, interests, social and culture.

The results of this study will first explain the social classes conflict, intergroup conflict, interpersonal conflict 
intergenerational conflict, social status and roles conflict that occur in the novel Si Anak Pelangi by Tere Liye:

\section{1) Social Classes Conflict}

Social classes conflict are usually in the form of vertical conflict or people and rulers, namely conflict between the upper social class that has higher power and the lower social class. Social classes conflicts are on page 161.

"Starting tomorrow you can no longer sell here! Pak Kiman threatened. If you still dare to sell, we will destroy your stall! Pak Kiman's supporters are no less fierce. Just try it if you dare! Egg sellers are challenging. You fight, huh? Now both groups are equally advanced. At first they pushed each other, then hit each other".

In the novel excerpt above, there is an social class conflict in which Pak Kiman's threats and acts of violence destroy the selling stalls and end up hitting each other.

\section{2) Intergroups Conflict}

Intergroups conflict occur between two social groups caused by different interests or because of the same conflict of interest, so there are efforts from each group to get what they want, so that sometimes groups use actions that are detrimental to other groups. Social classes conflicts are on page 288 .

"the letter contains harsh sentences. Swearing at Koko. Badmouthing this place. The language in the anonymous letter was very harsh. There is a sentence that ordered Koko to return to the land of his ancestors. Otherwise, this place will be destroyed".

There is a difference of interest that causes conflict between them. Sends a letter containing harsh sentences telling Koko to move or return to her home country. Threats like this make Koko scared because in the letter Koko's sales will be destroyed if she does not move or does not leave.

\section{3) Interpersonal Conflict}

This conflict can occur between two individuals since they met. Usually this happens if there is no sympathy between them from the start and they do not like each other. Interpersonal conflict is found on page 148.

"don't fight like children. This problem will not be solved with violence, instead you are staining this environment with commotion. The owner of the rice stall glared at the four youths. You and the others are still alert. We don't want to fight. This mother broke the deal. It's normal that we confiscate the refrigerator!"
The quarrel between the youth and the owner of the rice stall. The youth did not like Mother because she had violated the agreement that had been made, where the agreement was that the refrigerator was on credit, it should not be paid late at a specified time. It seems that what we know is that if the credit is not paid, it will be confiscated again.

\section{4) Intergenerational Conflict}

Intergenerational conflict is a conflict that occurs between two generations, namely the younger generation and the older generation due to differences in value orientations in society. Intergenerational conflict is on page 68.

"at one time, when the Popo family was considered a descendant, hated by some groups of people, this hotel became a target for that hatred. They hate us for the assumption that if a Popo ethnic group behaves badly, then everyone is evil. They argue that if a Popo ethnic group becomes a traitor, then everyone is a traitor. If Popo is a bandit, then Popo's entire family is a bandit."

The intergenerational conflict in this novel is the Popo family who is considered as a descendant who is hated by several groups of people who eat the hotel as a target because they carry their descendants. They think that Popo's descendants or ethnicity behave evil and traitors.

\section{5) Social Roles and Status Conflict}

Every individual who occupies a certain status or position in society and carries out a role, is sometimes faced with conflict related to his status and role. Conflict of social status and role can be found on pages 178-179.

“You know today is Yose's turn to picket class, Pak Cip explained. He came early in the morning, as usual accompanied by his mother. After leaving, as Yose prepared to pass through the gate, several young men approached him. At first they shrug, and Yose hands over all his pocket money. Next the men threatened, telling Yose that he couldn't go to school here. Black kids like Yose can't go to school here."

Status and social role, Yose had no choice because some young men bullied him at the school gate. Yose chose to give all his pocket money to the young man because he was threatened that Yose could not go to school here.

\section{Discussion}

In social conflict, human beings often interact interactions carried out by people or someone with other people and society. Conflict that can change and develop human life for the better or for the worse. Social conflict do 
not just happen, because there are complex factors ranging from ethnic strength, social class, and inequality. Conflict is one of the core of human life and development which has various characteristics. Social conflict is often one of the causes of community disputes and opposing each other. Basically, humans cannot live alone and must interact with the community in order to fulfill their needs. Social conflict arises along with the interactions carried out by a person or person with other people and society.

Conflict can be categorized into social problems, which come from differences to conflict of interpersonal and groups. Conflict can also have an impact on violence if individuals or groups cannot contain their emotions. Conflict can be avoided if we respect each other. Therefore, if humans do not immediately find a way out, it can lead to conflict. Conflict arise from individual attitudes towards the social environment regarding various issues, such as ideological conflict, rape of rights and others. Social conflict are caused by social contact between humans, or problems that arise due to conflict between one character and another. In this study, each study of social conflict consists of social classes conflict, intergroup conflict, interpersonal conflict intergenerational conflict, social status and roles conflict.

In this research study, there are five different forms of social conflict, namely (a) social classes conflict; (b) intergroup conflict; (c) interpersonal conflict; (d) intergenerational conflict; (e) social status and roles conflict. The following is an explanation of the forms of social conflict as follows:

\section{a) Social Classes Conflict}

Social conflict are usually in the form of vertical conflict or people and rulers, namely conflict between the upper social class that has higher power and the lower social class. In line with Mark in (Abidin, 2014, pp. 386-387) social class consists of free people and slaves, aristocrats and commoners, masters and servants, oppressors and the oppressed are always in conflict with each other which continues uninterruptedly in a fight that is sometimes hidden, and open.

In the excerpt of the novel on page 161 there is an inter-social class conflict in which Pak Kiman's threats and acts of violence destroy the selling stalls and end up hitting each other. The existence of blackmail on chicken sellers which resulted in a commotion in the market. The security money collector asked the chicken seller to give double the money and according to him it was unfair because the other sellers were not asked double and threatened him not to sell in the market and his stall was threatened to be closed. However, other sellers forbade the chicken seller to pay for it and the atmosphere at that time was getting worse and ended in a physical fight.

\section{b) Intergroups Conflict}

Conflict between groups occur between two social groups caused by different interests or because of the same conflict of interest, so there are efforts from each group to get what they want, so that sometimes groups use actions that are detrimental to other groups. This is in line with (Abidin, 2014, p. 279) stating that this type of conflict can occur due to the struggle for social mobility opportunities, for example the opportunity to obtain economic resources (land disputes between entrepreneurs and local residents), opportunities to gain political power, or community recognition.

In the excerpt of the novel on page 288 there are conflict between groups, differences in interests that lead to conflict between them. Sends a letter containing harsh sentences telling Koko to move or return to her home country. Threats like this scare Koko because in the letter Koko's sales will be destroyed if he does not move or does not leave. Koko did not want anyone to know about the letter. Om Tinap knows because the letter was sent to this post. It happened a long time ago but it happened again, during the riots in the city center, several people came to threaten and luckily Om and Pram stopped them.

\section{c) Interpersonal Conflict}

This conflict can occur between two individuals since they met. Usually this happens if there is no sympathy between them from the start and they do not like each other. Interpersonal conflict is a conflict that occurs between two individuals because of differences in interests or it could be due to the entry of individuals into groups that are not accepted by other group members.

Interpersonal conflict can be found on page 148, there is a fight between the youth and the owner of the rice stall. The youth did not like Mother because she had violated the agreement that had been made, where the agreement was that the refrigerator was on credit, it should not be paid late at a specified time. It seems that what we know is that if the credit is not paid, it will be confiscated again. There was a fight between Tante Sona and the four youths which resulted in a commotion and pushing each other. Residents asked to be resolved properly but the young man did not want to and said that the young man was only carrying out their duties because of an agreement that was broken. The agreement is that whoever credits an item must pay the installments until the time that has been promised by both parties previously, and Tante Sona does not pay the installments always in arrears and pretends to forget.

\section{d) Intergenerational Conflict}


Intergenerational conflict is a conflict that occurs between two generations, namely the younger generation and the older generation due to differences in value orientations in society. In line with opinion (Soetomo, 2013, p. 107) states that intergenerational conflict is a conflict that occurs between two generations, namely the younger generation and the older generation because of differences in value orientations in society. The younger generation, on the other hand, uses a new value orientation, they view the older generation as old-fashioned.

The intergenerational conflict is on page 68. The intergenerational conflict in this novel is the Popo family, who is considered a descendant that is hated by several groups of people who eat at the hotel. They are targeted because they carry their descendants. They think that Popo's descendants or ethnicity are evil and traitorous. With that understanding, Popo has no right to be here. That night, a group of people surrounded the hotel and shouted to chase the Popo family away. But Liem, Koko's father chose to stay. That night Popo had no fear even though the windows were shattered by stones. The flames from the Molotov cocktails began to burn as well as screams filled with hate speech from outside. The group of people managed to force open the door but suddenly someone was protecting Popo's family, they were Liem's friends, they formed a line and blocked the group that forced their way in.

\section{e) Social Status and Roles Conflict}

Every individual who occupies a certain status or position in society and carries out a role, is sometimes faced with conflict related to his status and role. In line with the opinion of Paul B. Horton in (Dhohiri, 2007, p. 16), defines status or position as a person's position in a social group.

Conflict of social status and roles are found on pages 178-179 of social status and roles, Yose had no choice because some youths bullied him at the school gate. Yose chose to give all his pocket money to the young man because he was threatened that Yose could not go to school here. Yose's friends asked Yose because during recess Yose was not family from class and not like others. Yose chose to study, opened and took out a book from his bag. Friends also asked what was wrong with Yose and suggested Yose permission from school but Yose chose to stay in class. His friends agreed not to take Yose out or to the canteen and leave studying in class. And it turns out that Yose got a threat when he entered the school gate and his pocket money was asked by a group of people he did not know.

\section{CONCLUSION}

The forms of social conflict are clearly seen in the novel Si Anak Pelangi by Tere Liye. There are five social conflict, including social classes conflict, intergroup conflict, interpersonal conflict intergenerational conflict, social status and roles conflict in the novel. Literary works, including novels, will incise conflict in their work, both their own experiences and those of others in order to attract the attention of readers and of course can be enjoyed by the audience. With a conflict made in a novel or a story that occurs within the scope of society or it can also be called a social conflict, it will be able to break other people or be curious about an interesting storyline.

The conflicts that exist in a story or novel will affect the number or interest of readers towards the novel. Often writers are not so indifferent to the existence of conflict in a novel because it will carry a negative theme or topic. Conflict is not always about negative things, there are also positive ones, for example in the novel Si Anak Pelangi. It is well known that conflict is able to make the readers curious. Conflict is very suitable to be written or inscribed on a work to make it interesting and not monotonous.

\section{REFERENCES}

[1] Abidin, Y. Z. (2014). Pengantar Sistem Sosial Budaya di Indonesia. Bandung: CV Pustaka Setia.

[2] Ahmadi, A. (2009). Psikologi Sosial. Jakarta: Rineka Cipta.

[3] Altenbernd, L. d. (1996). A Hand Book for the Study of Fiction. London: The Macmillan Company.

[4] Angi Saputri, d. (2016). Konflik Sosial Pada Novel Warisan Karya Chairul Harun. Jurnal Pendidikan Bahasa dan Sastra Indonesia.

[5] Dhohiri, T. R. (2007). Sosiologi I Suatu Kajian Kehidupan Masyarakat. Jakarta: Yudhistira.

[6] Minnery, J. R. (1985). Conflict management in urban planning. England: Gower Publishing Company Limited.

[7] Moleong, L. J. (2014). Metodologi Penelitian Kualitatif. Bandung: PT Remaja Rosdakarya.

[8] Nurgiyantoro, B. (2013). Teori Pengkajian Fiksi. Yogyakarta: Gadjah Mada University Press.

[9] Ratna, N. K. (2013). Teori, Metode, dan Teknik Penelitian Sastra. Denpasar: Pustaka Belajar.

[10] Soekanto, S. (2015). Sosiologi Suatu Pengantar. Jakarta: PT Rajawali Pers.

[11] Soetomo. (2013). Masalah Sosial dan Upaya Penanganannya. Yogyakarta: Pustaka Pelajar.

[12] Sugiyono. (2013). Metode Penelitian Kuantitatif, Kualitatif dan $R \& D$. Bandung: PT Alfabet.

[13] Sukmadinata, N. S. (2012). Metode Penelitian Pendidikan. Bandung: Rosda Karya.

[14] Tere Liye. (2021). Si Anak Pelangi. Depok: PT. Sabak Grup Nusantara

[15] Tumanggor, R. dkk. (2012). Ilmu Sosial Budaya \& Dasar. Jakarta: Kencana.

[16] Yu Hua. (2021). Hujan di Rinai Gerimis. Jakarta : PT. Gramedia Pustaka Utama. 